\title{
Optimization of raw acrylic yarn dye wastewater treatment by electrochemical processes: kinetic study and energy consumption
}

\author{
Ilhan F.*, Ulucan-Altuntas K.*, Dogan C. and Kurt U. \\ Yildiz Technical University, Environmental Engineering Department, Istanbul, Turkey \\ Received: 10/12/2018, Accepted: 07/02/2019, Available online: 15/02/2019 \\ *to whom all correspondence should be addressed: e-mail: filhan@yildiz.edu.tr \\ https://doi.org/10.30955/gnj.002980
}

\section{Abstract}

The textile industry has an important place in the environmental pollution due to its heavy water consumption and to the toxic content of dye. Every succeeding day, the water quality is deteriorated because the wastewater containing the dye is supplied to the receiving medium. In this study, The electrocoagulation and electrofenton processes, which produce less waste than the conventional methods and which are less costly, have been investigated for decolourization of acrylic yarn dyeing wastewater. The electrocoagulation process was involved four electrodes parallel connected. To optimize the treatment, response surface methodology (RSM) was applied. The operating independent conditions were selected as the current density $\left(20-100 \mathrm{~A} / \mathrm{m}^{2}\right)$, reaction time (5-25 minutes) and initial $\mathrm{pH}(\mathrm{pH} 4.3-\mathrm{pH} \mathrm{8.3).} \mathrm{As} \mathrm{a}$ result of optimization by RSM method, the highest Colour, COD and TOC removal were obtained as $96.2 \%, 43.8 \%$ and $40.4 \%$, respectively. In order to obtain these results, it was necessary to apply a current density of $100 \mathrm{~A} / \mathrm{m}^{2}$ to the wastewater which has been set to an initial $\mathrm{pH}$ of 7.2 and 20.7 minutes. With the experimental setup installed, high colour removal can be achieved in as little as 15 minutes. Although the colour removal is high, COD removal does not meet discharge standards. Therefore, electrofenton process was applied for enhancing COD and TOC removal and removal rate increased to $70.0 \%$ and $61.5 \%$, respectively. In order to study the removal mechanism for acrylic yarn dye wastewater by electrocoagulation process, kinetic modelling was applied. Energy consumption was also assessed.

Keywords: Electrofenton, electrocoagulation, parallel electrodes, aluminium, iron, kinetic modelling, energy consumption.

\section{Introduction}

The textile industry is one of the sectors on which emphasis should be put in terms of the prevention of the industrial pollution and the protection of the water resources. Textile industry to have an important position in the export and employment of the developing countries makes the subject more delicate. The wastewater of the textile industry is generally characterized with high COD, strong colour, high $\mathrm{pH}$, low biological refinability (Korbahti et al., 2011; Pons et al., 2005; Ulucan-Altuntas and IIhan, 2018) and many sub-branches of this industry due to the production of wastewater in very variable structures and volumes (Chaudhari and Tantak, 2006; Cinar et al., 2008). The fact that the textile industry has a very variable character of wastewater makes it difficult to treat generalization with a single treatment method. For this reason, it requires the separate examination of each production facility.

The treatment of textile wastewater is studied especially for the colour and COD removal and conducted with biological treatment methods (Cinar et al., 2008; Peres et al., 2007; Khataee et al., 2009), chemical and physicochemical methods (Gupta and Suhas, 2009) and membrane technologies (Dilek et al., 2008). Besides; various methods are used in the chemical oxidation processes such as ozone (Ulucan-Altuntas and ilhan, 2018; Sundrarajan et al., 2007). Electrochemical studies have also taken place in this area as well as these processes. Especially the processes of electrocoagulation and advanced oxidation have recently found a usage in this area.

In the electrocoagulation process $(E C)$; other than the chemical coagulation, the coagulant substances are given to the environment with the dissolution of Fe (Ulucan and Kurt, 2015; Kobya et al., 2014) or Al (Ulucan and Kurt, 2015; Kobya et al., 2014; Brillas and Martinez, 2009) metals chosen as the anode material during the electrolysis. The efficient parameters on the removal mechanism regarding the electrocoagulation process are the current density, not starting $\mathrm{pH}$, electrode type, settlement of the electrodes, bonding ways, conductivity and reaction period (Ulucan and Kurt, 2015; Sari Erkan et al., 2018).

The electrocoagulation process has a very wide usage spectrum. High yields could be obtained in areas such as leachate (Ilhan et al., 2008) whose treatment is the hardest and domestic wastewater (Kurt et al., 2008; Korbahti, 2014) whose treatment is much easier. In the textile industry, it is stated that the EC process is very 
effective especially in the colour removal (Phalankornkule et al., 2010). For instance; Gourich and his friends have investigated the efficiency of dyestuff removal using a mixed dysprosium red dyestuff solution with a continuous flow electrocoagulation process (Phalankornkule et al., 2010). In a study conducted with basic red 46 and basic blue 3 dyestuff solutions, the high removal efficiencies could be obtained (Gourich et al., 2009). Another method is the electrofenton process in which electrocoagulation and fenton processes are used together. Electrocoagulation is basically considered to be the developed condition of chemical coagulation (Ilhan et al., 2017). From this point of view, the electrofenton process is a process in which the classical fenton process is carried out by means of an electric current through the ironwater transition.

The purpose of this study is to examine the removal efficiencies of COD, Colour and TOC parameters by means of electrocoagulation and electrofenton processes the most important pollutant parameters are taking place in the acrylic yarn dyeing bath and provide their optimisation with the method of Response Surface Methodology (RSM).

\section{Material and method}

\subsection{Wastewater}

The used wastewater in the experimental studies has been attained from acrylic yarn dye house. In the facility, acrylic yarns are taken to dyeing process without being subjected to pre-finishing process. Dye bath wastewater and bath wash water occurring after dyeing are accumulated in a balancing pool and refined by chemical method without being combined with domestic wastewater. Experimental studies have been carried out with wastewater taken in separate periods of time from acrylic dye bathes due to the fact that the dye bath waters represent the wastewater of the facility. Table 1 contains some parameters of dye bath waters. Basic dyestuff is used in the acrylic dye bath. The chemical structure of the used dispergator is alkylpolycolether, and it is non-ionic. COD, colour and TOC analysis's were performed under SM 5220C, SM $2120 \mathrm{E}$ and 5310B and all the chemicals were in a technical grade.

Table 1. Properties of the acrylic yarn dye wastewaters

\begin{tabular}{|c|c|c|c|c|c|c|c|}
\hline \multirow{2}{*}{ COD mg/L } & \multirow{2}{*}{ TOC mg/L } & \multicolumn{4}{|c|}{ Colour } & \multirow{2}{*}{$\mathrm{pH}$} & \multirow{2}{*}{ Conductivity $\mu \mathrm{s} / \mathrm{cm}$} \\
\hline & & $\Lambda_{436}$ & $\Lambda_{525}$ & $\Lambda_{620}$ & Abs & & \\
\hline 1.550 & 551 & 0.182 & 0.149 & 0.135 & 0.466 & 4.32 & 2.150 \\
\hline
\end{tabular}

\subsection{Experimental studies}

The Experimental studies on the electrocoagulation process have been carried out with $250 \mathrm{~mL}$ samples in Plexiglas reactors. Reactor dimensions are $6.5 \mathrm{~cm} \mathrm{x}$ $6.5 \mathrm{~cm} \times 18 \mathrm{~cm}$ and $\mathrm{Fe}$ and Al electrodes have been used in dimensions of $5 \mathrm{~cm} \times 18 \mathrm{~cm}$. In the experimental studies, 4 electrodes with a total active anode area of 101 $\mathrm{cm}^{2}$ have been placed at $15 \mathrm{~mm}$ intervals and connected in an unipolar parallel.

In the electrofenton experiments, $250 \mathrm{~mL}$ samples have been placed in the reactor cells made of Plexiglas, and the experimental apparatus used in the electrocoagulation experiments have been utilized. Unlike the electrocoagulation experiment apparatus, two electrodes have been used as 1 anode and 1 cathode in the electrofenton experiments and the electrode intervals have been determined as $6 \mathrm{~cm}$.

\subsection{Optimization method}

In this study, D-optimal design method provided by a computer algorithm called response surface methodology has been used in order to optimize the experimental data. It is a design that reveals the relationship between the dependent variables and the set of the independent variables in an appropriate manner. In order to see the effects of the variables and find the optimum conditions, the following second-degree polynomial regression model has been used.

$$
y=a_{0}+\sum a_{i} x_{i}+\sum a_{i j} x_{i} x_{j}+\sum a_{i i} x_{i}^{2}
$$

Here; $y$ shows the response variables, $a_{0}$ is the constant, $a_{i}, a_{i i}$ and $a_{i j}$ show the linear coefficients and $x_{i}, x_{j}$ show the independent variables. Variables have been coded within the direction of the following equation.

$$
\alpha=\frac{x_{i}-x_{0}}{\Delta x}
$$

Here; $\alpha$ gives the code value of the independent variables, $\mathrm{e} ; \mathrm{x}_{\mathrm{i}}$ give the real value, $\mathrm{x}_{\mathrm{o}}$ gives the real value in the medium point and $\Delta x$ gives the change in $x_{i}$ variable.

Table 2. Study matrix for the electrocoagulation

\begin{tabular}{ccccccc}
\hline \multirow{2}{*}{ Independent variables } & Factor & \multicolumn{5}{c}{ Levels } \\
\cline { 2 - 7 } & $\mathbf{X}_{\mathbf{j}}$ & $\boldsymbol{\alpha = - 2}$ & $\mathbf{- 1}$ & $\mathbf{0}$ & $\mathbf{+ 1}$ & $\boldsymbol{\alpha}=\boldsymbol{+ 2}$ \\
\hline Current Density $\left(\mathrm{A} / \mathrm{m}^{2}\right)$ & $\mathrm{X}_{1}$ & 20 & 40 & 60 & 80 & 100 \\
\hline Initial $\mathrm{pH}$ & $\mathrm{X}_{2}$ & 4.3 & 5.3 & 6.3 & 7.3 & 8.3 \\
\hline Reaction time $(\mathrm{min})$ & $\mathrm{X}_{3}$ & 5 & 10 & 15 & 20 & 25 \\
\hline
\end{tabular}

A five-level three-factor central composite design was applied for electrocoagulation process and current
Density $(\mathrm{x} 1)$, initial $\mathrm{pH}(\mathrm{x} 2)$ and reaction time $(\mathrm{x} 3)$ are the selected independent variables, and the levels of the 
variables are coded as $-2,-1,0,+1$ and +2 . Codded factors belong to electrocoagulation process are given in Table 2 .

\subsection{Kinetic modelling}

Dissolved $\mathrm{Al}^{+3}$ and $\mathrm{Fe}^{+2} / \mathrm{Fe}^{+3}$ ions from anode electrodes in electrocoagulation process forms into metal hydroxides with high adsorption capacity. In order to understand removal mechanism, Pseudo 1 and Pseudo 2 kinetic models were applied (Ulucan and Kurt, 2015). Pseudo-first-order kinetic model can be linearized as follows,

$$
\ln \left(q_{e_{1}}-q_{t}\right)=\ln q_{e}-k_{1} t
$$

where, $q_{e}$ and $q_{t}$ are the adsorption capacities at equilibrium and at a given time, $k_{1}$ is constant rate of adsorption ( $\mathrm{g} / \mathrm{mg} / \mathrm{min})$. Pseudo-second-order kinetic model is given in the following:

$$
\frac{t}{q_{t}}=\frac{1}{k_{2} q_{e}{ }^{2}}+\frac{1}{q_{e}} t
$$

where, $k_{2}$ is a constant rate of adsorption for pseudosecond-order-kinetic model (g/mg/min).

\section{Results and discussion}

\subsection{Electrocoagulation process}

The current density, $\mathrm{pH}$ and time values to be used in the response surface model have been detected within the direction of the literature information. Considering the own $\mathrm{pH}$ value $(\mathrm{pH}=4.3)$ of the acrylic yarn dye wastewater, the $\mathrm{pH}$ range has been determined as 4.3-8.3 for the purpose of examining the effects of acidic, neutral and basic starting $\mathrm{pH}$. The data of the preliminary study conducted with acrylic yarn dye wastewater has been benefited in the determination of the current density. In the study conducted by Daneshvar et al. (Daneshvar et al., 2006) with 2 different basic dyestuff, it has been found that the colour could be highly removed at a current density of $60-80 \mathrm{~A} / \mathrm{m}^{2}$ (Daneshvar et al., 2006). Because of the use of basic dyes in acrylic yarn dyeing, initial not flow density in the preliminary work has been selected as $60 \mathrm{~A} / \mathrm{m}^{2}$ for both electrode types. The obtained results are given in Table 4. The $\mathrm{pH}$ is set at 6 in the study conducted with aluminium electrodes and at 7 in the study conducted with iron electrodes. The treatment time has been chosen as 15 minutes.

Table 3. Results of the preliminary study conducted for the electrocoagulation process

\begin{tabular}{ccccc}
\hline \multirow{2}{*}{ Current density $\left(\mathbf{A} / \mathbf{m}^{2}\right)$} & \multicolumn{2}{c}{ Al electrodes } & \multicolumn{2}{c}{ Fe electrodes } \\
\cline { 2 - 5 } & COD removal (\%) & Colour removal (\%) & COD removal (\%) & Colour removal (\%) \\
\hline 60 & 29.73 & 86.23 & 34.93 & 96.79 \\
\hline 80 & 31.92 & 88.32 & 37.12 & 97.13 \\
\hline 100 & 32.58 & 88.53 & 38.53 & 95.32 \\
\hline 150 & 31.78 & 89.57 & 38.97 & 95.21 \\
\hline 200 & 34.03 & 90.85 & 39.59 & 94.05 \\
\hline 250 & 36.19 & 90.65 & 41.13 & 96.13 \\
\hline
\end{tabular}

\begin{tabular}{|c|c|c|c|c|c|c|c|}
\hline No. & $\begin{array}{l}\text { Current density } \\
\qquad\left(\mathrm{A} / \mathrm{m}^{2}\right)\end{array}$ & $\begin{array}{c}\text { Not } \\
\text { influent } \\
\mathrm{pH}\end{array}$ & $\begin{array}{l}\text { Reaction } \\
\text { time (min) }\end{array}$ & $\begin{array}{c}\text { COD removal } \\
\text { (\%) }\end{array}$ & $\begin{array}{c}\text { Colour removal } \\
\text { (\%) }\end{array}$ & $\begin{array}{c}\text { TOC removal } \\
\text { (\%) }\end{array}$ & $\begin{array}{l}\text { Energy consumption } \\
\qquad\left(\mathrm{kWh} / \mathrm{m}^{3}\right)\end{array}$ \\
\hline & $x_{1}$ & $x_{2}$ & $x_{3}$ & $y_{1}$ & $y_{2}$ & $y_{3}$ & $y_{4}$ \\
\hline 1 & -1 & -1 & -1 & 23.03 & 85.13 & 19.64 & 1.26 \\
\hline 2 & 1 & -1 & -1 & 30.15 & 87.13 & 26.72 & 4.59 \\
\hline 3 & -1 & 1 & -1 & 22.64 & 83.43 & 19.09 & 1.2 \\
\hline 4 & 1 & 1 & -1 & 29.07 & 85.65 & 25.38 & 4.54 \\
\hline 5 & -1 & -1 & 1 & 26.13 & 87.04 & 22.31 & 2.52 \\
\hline 6 & 1 & -1 & 1 & 34.03 & 89.92 & 30.45 & 9.18 \\
\hline 7 & -1 & 1 & 1 & 25.66 & 85.34 & 22.38 & 2.4 \\
\hline 8 & 1 & 1 & 1 & 32.17 & 88.89 & 28.71 & 9.07 \\
\hline 9 & 0 & 0 & 0 & 30.52 & 88.74 & 27.11 & 4.21 \\
\hline 10 & 0 & 0 & 0 & 30.26 & 88.65 & 26.75 & 4.21 \\
\hline 11 & 0 & 0 & 0 & 30.15 & 88.96 & 26.85 & 4.21 \\
\hline 12 & 0 & 0 & 0 & 30.21 & 89.36 & 26.61 & 4.21 \\
\hline 13 & -2 & 0 & 0 & 21.85 & 82.06 & 17.65 & 0.67 \\
\hline 14 & 2 & 0 & 0 & 33.45 & 88.4 & 30.08 & 10.61 \\
\hline 15 & 0 & -2 & 0 & 29.85 & 87.68 & 26.14 & 4.7 \\
\hline 16 & 0 & 2 & 0 & 29.38 & 84.78 & 25.59 & 4.03 \\
\hline 17 & 0 & 0 & -2 & 22.25 & 85.13 & 18.61 & 1.4 \\
\hline 18 & 0 & 0 & 2 & 31.24 & 89.15 & 27.73 & 7.02 \\
\hline 19 & 0 & 0 & 0 & 30.35 & 88.45 & 26.61 & 4.21 \\
\hline 20 & 0 & 0 & 0 & 30.67 & 89.09 & 27.28 & 4.21 \\
\hline
\end{tabular}

Table 4. RSM results conducted with aluminium electrodes 
As it could be seen in Table 3; no significant increase in COD and colour removal is observed when the current density is increased from $100 \mathrm{~A} / \mathrm{m}^{2}$ to $200 \mathrm{~A} / \mathrm{m}^{2}$ for both electrode types. For this reason, considering the energy consumption, the current density of $100 \mathrm{~A} / \mathrm{m}^{2}$ has been determined as the upper limit value in the statistical model for both iron and aluminium electrodes. The generated Box-Wilson test set and results are given in
Tables 4 and 5, aluminium and iron electrodes according to the study matrix is given in Table 2 .

Based on the given results in Tables 4 and 5 , the results of the ANOVA conducted for COD, Colour, TOC removal efficiencies and energy consumption of both aluminium and iron electrodes are given in Table 6 . It could be said that the meaningfulness of each one of them is high. Equations obtained according to this are given in Table 7.

Table 5. RSM results conducted with iron electrodes

\begin{tabular}{|c|c|c|c|c|c|c|c|}
\hline No. & $\begin{array}{l}\text { Current density } \\
\qquad\left(\mathrm{A} / \mathrm{m}^{2}\right)\end{array}$ & $\begin{array}{c}\text { Not } \\
\text { influent } \\
\text { pH }\end{array}$ & $\begin{array}{l}\text { Reaction } \\
\text { time (min) }\end{array}$ & $\begin{array}{c}\text { COD } \\
\text { removal (\%) }\end{array}$ & $\begin{array}{c}\text { Colour removal } \\
(\%)\end{array}$ & $\begin{array}{c}\text { TOC removal } \\
(\%)\end{array}$ & $\begin{array}{l}\text { Energy consumption } \\
\left(\mathrm{kWh} / \mathrm{m}^{3}\right)\end{array}$ \\
\hline & $x 1$ & $x 2$ & $x 3$ & y1 & y2 & y3 & y4 \\
\hline 1 & -1 & -1 & -1 & 27.05 & 90.21 & 21.25 & 1.01 \\
\hline 2 & 1 & -1 & -1 & 34.8 & 94.04 & 31.71 & 3.24 \\
\hline 3 & -1 & 1 & -1 & 30.23 & 92.77 & 27.83 & 0.96 \\
\hline 4 & 1 & 1 & -1 & 35.75 & 94.68 & 32.57 & 6.84 \\
\hline 5 & -1 & -1 & 1 & 28.85 & 91.49 & 25.75 & 2.02 \\
\hline 6 & 1 & -1 & 1 & 37.59 & 95.32 & 33.17 & 6.37 \\
\hline 7 & -1 & 1 & 1 & 34.25 & 94.47 & 31.11 & 1.91 \\
\hline 8 & 1 & 1 & 1 & 38.74 & 96.81 & 34.45 & 3.19 \\
\hline 9 & 0 & 0 & 0 & 35.25 & 96.6 & 32.63 & 2.81 \\
\hline 10 & 0 & 0 & 0 & 35.65 & 95.96 & 32.44 & 2.81 \\
\hline 11 & 0 & 0 & 0 & 36.18 & 96.11 & 32.89 & 2.81 \\
\hline 12 & 0 & 0 & 0 & 35.41 & 95.85 & 32.51 & 2.81 \\
\hline 13 & -2 & 0 & 0 & 26.44 & 89.36 & 24.92 & 0.46 \\
\hline 14 & 2 & 0 & 0 & 38.86 & 96.15 & 35.46 & 7.37 \\
\hline 15 & 0 & -2 & 0 & 27.89 & 90.43 & 22.96 & 3.29 \\
\hline 16 & 0 & 2 & 0 & 34.65 & 95.38 & 33.03 & 2.68 \\
\hline 17 & 0 & 0 & -2 & 27.37 & 91.74 & 25.02 & 0.96 \\
\hline 18 & 0 & 0 & 2 & 36.97 & 96.38 & 33.83 & 4.68 \\
\hline 19 & 0 & 0 & 0 & 35.73 & 96.23 & 32.37 & 2.81 \\
\hline 20 & 0 & 0 & 0 & 36.05 & 95.74 & 33.13 & 2.81 \\
\hline
\end{tabular}

Table 7 shows the equations obtained by choosing the effective parameters in a way that the confidence range will be $p>0.05$. It could be expressed from the attained equations that the initial $\mathrm{pH}$ is more effective in iron electrodes than aluminium electrodes. While the only current density and reaction time is effective in removing COD and TOC with aluminium electrodes, initial $\mathrm{pH}$ is also effective in COD and TOC removal with iron electrodes. The three selected variables have been found to be Table 6. ANOVA results attained for electrocoagulation

\begin{tabular}{|c|c|c|c|c|}
\hline Electrode & Dependent variables & Coded & $\mathbf{R}^{2}$ & Relevance \\
\hline \multirow{4}{*}{$\mathrm{Al}$} & COD Removal & $\mathrm{y}_{1}$ & 0.989 & 4.97 E-07 \\
\hline & Colour Removal & $y_{2}$ & 0.992 & $6.56 \mathrm{E}-08$ \\
\hline & TOC Removal & $y_{3}$ & 0.991 & $1.24 \mathrm{E}-07$ \\
\hline & Energy Consumption & $\mathrm{y}_{4}$ & 0.998 & $1.03 \mathrm{E}-11$ \\
\hline \multirow{4}{*}{$\mathrm{Fe}$} & COD Removal & $\mathrm{y}_{1}$ & 0.990 & $2.65 \mathrm{E}-07$ \\
\hline & Colour Removal & $y_{2}$ & 0.992 & 8.27 E-08 \\
\hline & TOC Removal & $y_{3}$ & 0.988 & $5.27 \mathrm{E}-07$ \\
\hline & Energy Consumption & $\mathrm{y}_{4}$ & 0.940 & $1.27 \mathrm{E}-03$ \\
\hline
\end{tabular}

effective in colour removal conducted with the both aluminium and iron electrodes. In the case of energy consumption, it has been seen that only the current density effect is observed in the study conducted with iron electrodes, while the reaction time is also effective as well as the current density in the study conducted with the aluminium electrodes. 
Table 7. Equations attained with aluminium and iron electrodes

\begin{tabular}{ccc}
\hline Electrode & Dependent variables & Equation \\
\hline \multirow{3}{*}{ Al } & COD Removal & $\mathrm{y}_{1}=30.227+3.198 \mathrm{x}_{1}+1.943 \mathrm{x}_{3}-0.744 \mathrm{x}_{1}{ }^{2}-0.97 \mathrm{x}_{3}{ }^{2}$ \\
\cline { 2 - 3 } & Colour Removal & $\mathrm{y}_{2}=88.82+1.458 \mathrm{x}_{1}-0.732 \mathrm{x}_{2}+1.118 \mathrm{x}_{3}-0.939 \mathrm{x}_{1}{ }^{2}-0.689 \mathrm{x}_{3}{ }^{2}$ \\
\cline { 2 - 3 } & TOC Removal & $\mathrm{y}_{3}=26.758+3.294 \mathrm{x}_{1}+1.954 \mathrm{x}_{3}-0.98 \mathrm{x}_{3}{ }^{2}$ \\
\cline { 2 - 3 } $\mathrm{Fe}$ & Energy Consumption & $\mathrm{y}_{4}=4.163+2.493 \mathrm{x}_{1}+1.426 \mathrm{x}_{3}+0.833 \mathrm{x}_{1} \mathrm{x}_{3}-0.334 \mathrm{x}_{1}{ }^{2}$ \\
\cline { 2 - 3 } & COD Removal & $\mathrm{y}_{1}=35.79+3.21 \mathrm{x}_{1}+1.513 \mathrm{x}_{2}+1.925 \mathrm{x}_{3}-1.07 \mathrm{x}_{2}{ }^{2}-0.844 \mathrm{x}_{3}{ }^{2}$ \\
\cline { 2 - 3 } & Colour Removal & $\mathrm{y}_{2}=96.04+1.593 \mathrm{x}_{1}+1.10 \mathrm{x}_{2}+0.979 \mathrm{x}_{3}-0.853 \mathrm{x}_{1}{ }^{2}-0.815 \mathrm{x}_{2}{ }^{2}-0.526 \mathrm{x}_{3}{ }^{2}$ \\
\cline { 2 - 3 } & TOC Removal & $\mathrm{y}_{3}=32.60+2.94 \mathrm{x}_{1}+2.14 \mathrm{x}_{2}+1.80 \mathrm{x}_{3}-1.20 \mathrm{x}_{2}{ }^{2}-0.84 \mathrm{x}_{3}{ }^{2}$ \\
\cline { 2 - 3 } & Energy Consumption & $\mathrm{y}_{4}=2.82+1.723 \mathrm{x}_{1}$ \\
\hline
\end{tabular}

According to the efficient parameters; COD, Colour and TOC removal efficiencies attained with the iron and aluminium electrodes and the attained quadratic surface plots are given in Figures 1 and 2.

COD Removal Efficiency $\left(y_{1}\right)$ is given in Figure 1 with showing the effects of current density $\left(x_{1}\right)$ and the reaction time $\left(x_{3}\right)$ at the point $\alpha=0$ for initial $\mathrm{pH}\left(\mathrm{x}_{2}\right)$ which is $\mathrm{pH}$ 6.3. It can be seen from the surface plot that when the current density and reaction time are increasing the removal rate is increased. It can be observed from the coefficient of independent variables given in Table 7 that, while initial $\mathrm{pH}\left(x_{2}\right)$ is not effective in COD and TOC removal efficiency with aluminium electrodes, it is effective in Colour Removal Efficiency. Low pH values are found to be more effective in Colour removing efficiency
$(0>\alpha>-0.5-5.8<\mathrm{pH}<6.3)$ and current density is found to be more effective at the point of $0.5<\alpha<1.5$ which is $70-80$ $\mathrm{A} / \mathrm{m}^{2}$ (Figure 1.b). Kobya et al. were also found that lower than $\mathrm{pH} 6$ is more effective in COD removal with aluminium electrodes while higher than $\mathrm{pH} 7$ was found to be more effective with iron electrodes (Kobya et al., 2003). In addition, COD removal efficiencies were also lower as obtained in this study (Kobya et al., 2003). In Figure 1.c TOC Removal Efficiency $\left(y_{3}\right)$ can be observed with effect of current density $\left(x_{1}\right)$ and the reaction time $\left(x_{3}\right)$. Removable TOC is found to be around $32 \%$ with a reaction time higher than 18 minutes and with a current density higher than $90 \mathrm{~A} / \mathrm{m}^{2}$.
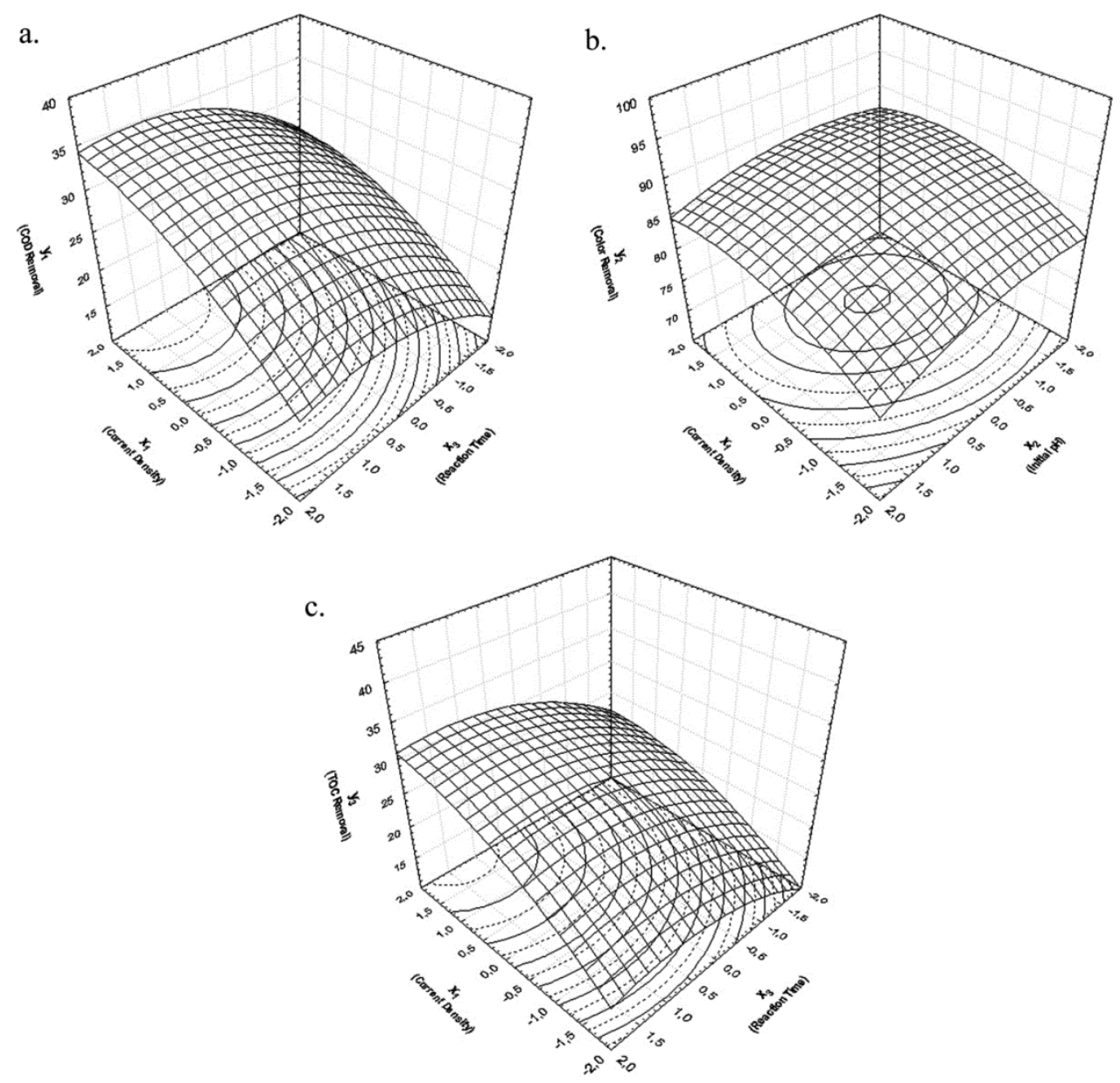

Figure 1. COD, Color and TOC Removal by Aluminium electrodes 
COD, colour and TOC removal efficiencies by iron electrodes can be seen in Figures 2.a, 2.b and 2.c, respectively. In Figure 2, the effects of current density $\left(x_{1}\right)$ and the reaction time $\left(x_{3}\right)$ on COD removal efficiency can be noticed at the point $\alpha=0$ for initial $\mathrm{pH}\left(\mathrm{x}_{2}\right)$ which is $\mathrm{pH}$ 6.3. The highest COD removal efficiency can be obtained with reaction time higher than 18 minutes and current density higher than $90 \mathrm{~A} / \mathrm{m}^{2}$. In Figure 2.b, colour removal efficiency can be seen with the effect of initial $\mathrm{pH}\left(x_{2}\right)$ and current density. Range of initial $\mathrm{pH}$ with $\mathrm{pH} 6.3$ and $\mathrm{pH} 7.8$ is found to be more effective. From Figure 2.c it can be obtained that the current density is more effective than reaction time on TOC removal.
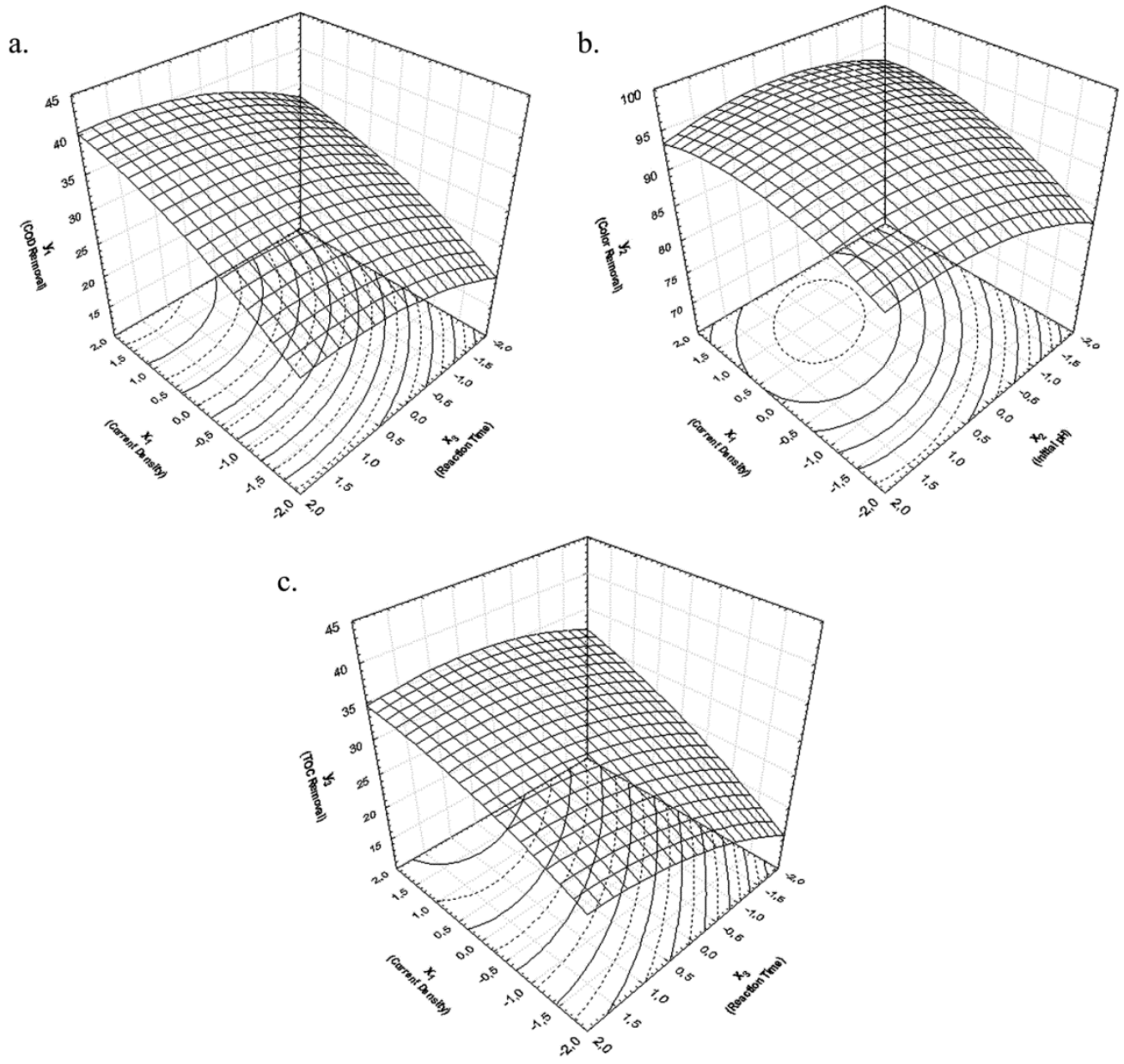

Figure 2. COD, Colour and TOC Removal by Iron electrodes

As it could be seen in Figures 1 and 2; approximately 40\% removal could be achieved with iron electrodes, while $35 \%$ removal could be achieved with the aluminium electrodes in COD removal. It is seen that TOC removal is similar to that of COD and the colour removal is approximately and respectively by $90 \%$ and $95 \%$ for the aluminium and iron electrodes. When the electrodes are compared, it has been observed that iron electrodes are more effective than aluminium electrodes. This situation has been realized as expected in terms of COD removal. It is generally specified that iron electrodes are as effective as aluminium electrodes in the removal of COD from wastewater. This is due to the fact that the iron oxidation capacity increases the efficiency of COD removal (Diaz et al., 2009).
The equations attained for the iron electrodes are given in Table 7 and the codes attained as a result of the optimization conducted with the help of MathCad and the values belonging to the independent variables are given in Table 8 . The results also correspond to the data obtained from the surface plots. $43.8 \%$ COD, 96.2\% Colour and $40.4 \%$ TOC removal could be achieved according to these optimized values. When optimum conditions are applied in electrocoagulation process, $42.9 \%$ COD, $98 \%$ colour, $41.1 \%$ TOC removal was obtained which are in the $95 \%$ confidence interval. The Required energy was calculated as $6.27 \mathrm{kWH} / \mathrm{m}^{3}$ textile wastewater. Energy consumption in Turkey was 0.08 US $\$ / \mathrm{kWH}$ for industry.the cost of electrocoagulation process by iron electrodes will be 0.50 US $\$ / \mathrm{m}^{3}$ textile wastewater. 
Table 8. Optimization of electrocoagulation process

\begin{tabular}{ccc}
\hline Independed factors & Coded levels & Real values \\
\hline Current Density $\left(\mathrm{A} / \mathrm{m}^{2}\right)$ & 2 & 100 \\
\hline Initial $\mathrm{pH}$ & 0.892 & $\mathrm{pH} 7.2$ \\
\hline Reaction Time $(\mathrm{min})$ & 1.14 & 20.7 \\
\hline
\end{tabular}

Pseudo-first-order and pseudo-second-order kinetic models were investigated to consider removal mechanism involved in electrocoagulation process. Correlation coefficients and constant rates of kinetic models were given in Table 9. The results showed that colour, COD and TOC removal mechanism is more fitted to pseudo-firstorder kinetic model. By this information it can be said that the removal of these three parameters is also occurred by adsorption on metal hydroxides and the three parameters are not affecting each other in the removal. In addition, highest adsorption capacity for COD and TOC was calculated as 678.5 and $249.4 \mathrm{mg} / \mathrm{g}$ iron hydroxide.

Table 9. Kinetic modeling for electrocoagulation process with iron electrodes

\begin{tabular}{cccc}
\hline \multicolumn{2}{c}{ Parameters } & $\begin{array}{c}\text { Pseudo-first-order } \\
\text { kinetic }\end{array}$ & $\begin{array}{c}\text { Pseudo-second- } \\
\text { order kinetic }\end{array}$ \\
\hline Colour & $\mathrm{R}^{2}$ & 0.988 & 0.972 \\
\hline & $\mathrm{q}_{\mathrm{e}}$ & 0.068 & 0.005 \\
\hline COD & $\mathrm{R}^{2}$ & 0.937 & 0.792 \\
\hline & $\mathrm{q}_{\mathrm{e}}$ & 678.5 & 2.917 \\
\hline $\mathrm{TOC}$ & $\mathrm{R}^{2}$ & 0.932 & 0.791 \\
\hline & $\mathrm{q}_{\mathrm{e}}$ & 249.4 & 8.166 \\
\hline
\end{tabular}

\subsection{Electrofenton process}

While colour removal could be achieved in high ratio with the electrocoagulation process, it has been seen that the COD and TOC removal have remained by the ratio of $40 \%$. The electrofenton process has been applied within the direction of the study data attained as a result of the optimization of the electrocoagulation process and its impact on the efficiency has been desired to be observed. According to our previous studies (Ulucan and Kurt, 2015; Ilhan et al., 2017) and also to minimize the treatment cost, $\mathrm{pH}$ of the wastewater has been adjusted as 3 and the used $\mathrm{H}_{2} \mathrm{O}_{2}$ concentration is $1200 \mathrm{mg} / \mathrm{L}$. Time has been chosen as 30 minutes.

Table 10. Removal efficiencies with electrofenton process

\begin{tabular}{cccc}
\hline $\begin{array}{c}\text { Current } \\
\text { density, } \\
\mathbf{A} / \mathbf{m}^{\mathbf{2}}\end{array}$ & $\begin{array}{c}\text { COD } \\
\text { removal } \\
\text { rate,\% }\end{array}$ & $\begin{array}{c}\text { Colour } \\
\text { removal } \\
\text { rate, } \%\end{array}$ & $\begin{array}{c}\text { TOC removal } \\
\text { rate, \% }\end{array}$ \\
\hline 50 & 51.4 & 81.9 & 42.9 \\
\hline 100 & 70.0 & 94.2 & 61.5 \\
\hline 150 & 67.7 & 99.0 & 59.2 \\
\hline 200 & 70.3 & 97.2 & 63.1 \\
\hline
\end{tabular}

As seen in Table 10; COD, Colour and TOC removals have been attained as respectively $70.0 \%, 94.2 \%$ and $61.5 \%$ when a current density of $100 \mathrm{~A} / \mathrm{m}^{2}$ is applied. The Removal could be achieved in a higher ratio when it is compared to the electrocoagulation.

When electrofenton and electrocoagulation processes compared on cost, the difference will be occurred by hydrogen peroxide usage. Since the cost of $50 \%$ hydrogen peroxide in technical quality is $\$ 400 /$ ton, approximate $\mathrm{H}_{2} \mathrm{O}_{2}$ cost will be $\$ 0.8 / \mathrm{m}^{3}$ wastewater.

\section{Conclusion}

In this study in which the treatments of the wastewater of the acrylic yarn dye house both with electrofenton process and electrocoagulation process have been examined. With the kinetic modelling study, it is understood that removal of COD, colour and TOC are not affecting each other and adsorption on metal hydroxides is an effective removal mechanism on electrocoagulation process. Energy consumption is also studied and the required energy is calculated as $6.27 \mathrm{kWH} / \mathrm{m}^{3}$ textile wastewater which costs 0.50 US $\$ / \mathrm{m}^{3}$ textile wastewater.

In addition, it has been observed that the electrofenton process is much more effective when it is compared to the electrocoagulation process. While colour removal could be achieved in higher removal rate with the electrocoagulation process, it has been seen that it is insufficient in the issue of COD and TOC removal. In this meaning, electrofenton process has been applied for the purpose of increasing the COD and TOC removals and discovering that removal could be achieved by the ratio of $70.0 \%$ and $61.5 \%$ has been attained. An innovative approach, such as the use of nanoparticles in the fentonlike processes could enhance the COD and TOC removal.

\section{Acknowledgements}

This research received no specific grant from any funding agency in the public, commercial, or not-for-profit sectors.

\section{References}

Brillas E. and Martinez C.A. (2009), Decontamination of wastewaters containing synthetic organic dyes by electrocoagulation methods: a general review, Applied Catalysis B: Environmental, 87, 105-145.

Chaudhari S. and Tantak N.P. (2006), Degradation of azo dyes by sequential Fenton oxidation and aerobic biological treatment, Journals of Hazardous Materials, B136, 698-705.

Cinar O., Yaşar S., Kertmen M., Demiröz K., Yiğit A.Ö. and Kitis M. (2008), Effect of cycle on biodegradation of azo dye in sequencing batch reactor, Process Safety and Environment Protection, 86, 455-460.

Daneshvar N., Oladegaragoze A. and Djafarzadeh A. (2006), Decoloriztion of basic dye solutions by electrocoagulation an investigation of the effect of operational parameters, Journal of Hazardous Materials, B129, 116-122.

Diaz C.B., Hernandez I.L., Morales G.R., Bilyeu B. and UrenaNunez F. (2009), Influence of the anodic material on electrocoagulation performance, Chemical Engineering Journal, 148, 97-105. 
Dilek F.B., Sahinkaya E., Uzal N. and Yetis U. (2008), Biological treatment and nanofiltration of denim textile wastewater for reuse, Journals of Hazardous Materials, 153, 1142-1148.

Gourich B., Merzouk B., Seki A., Madani K., Vial Ch. and Barkaoui M. (2009), Studies on the decolorization of textile dye wastewater by continuous electrocoagulation process, Chemical Engineering Journal, 149, 207-214.

Gupta V.K. and Suhas (2009), Application of low-cost adsorbents for dye removal - a review, Journal of Environmental Management, 90, 2313-2342.

Ilhan F., Kurt U., Apaydın Ö. and Gönüllü M.T. (2008), Treatment of leachate by electrocoagulation using Aluminium and Iron Electrodes, Journal of Hazardous Materials, 154, 381-389.

Ilhan F., Yetilmezsoy K., Kabuk H.A., Ulucan K., Coskun T. and Akoglu B. (2017), Evaluation of operational parameters and its relation on the stoichiometry of Fenton's oxidation to textile wastewater, Chemical Industry \& Chemical Engineering Quarterly, 23(1), 11-19.

Khataee A.R., Vatanpour V. and Amani Ghadim A.R. (2009), Decolarization of C.I. acid blue 9 solution by UV/Nano-TiO Fenton, Fenton-like, Electro-Fenton and electrocoagulation processes: a comparative study, Journal of Hazardous Materials, 161, 1225-1233.

Kobya M., Can O.T. and Bayramoglu M. (2003), Treatment of textile wastewaters by electrocoagulation using iron and aluminium electrodes, Journal of Hazardous Materials, 100(1-3), 163-178.

Kobya M., Gengec E., Sensoy M.T. and Demirbas E. (2014), Treatment of textile wastewater by electrocoagulation using Fe and Al electrodes: optimisation of operating parameters using central composite design, Coloration Technology, 130, 226-235.

Korbahti B., Artut K., Gecgel C. and Ozer A. (2011), Electrochemical decolorization of textile dyes and removal of metal ions from textile dye and metal ion binary mixtures, Chemical Engineering Journal, 173, 677-688.

Korbahti B. (2014), Finite element modeling of continuous flow tubular electrochemical reactor for industrial and domestic wastewater treatment, Journal of the Electrochemical Society, 161, E3225-E3234.

Kurt U., Gönüllü M.T., İlhan F. and Varınca K. (2008), Treatment of domestic wastewater by electrocoagulation in a cell with Fe-Fe electrodes, Environmental Engineering Science, 25(2), 153-161.

Peres J.A., Lucas M.S., Dias A.A., Sampaio A. and Amaral C. (2007), Degradation of textile reactive azo dye by a combined chemical-biological process: Fenton's reagentyeast, Water Research, 41, 1103-1109.

Phalankornkule C., Polgumhang S., Tongdaung W., Karakat B. and Nuyut T. (2010), Electrocoagulation of blue reactive, red disperse and mixed dyes and application in treating textile effluent, Journal of Environmental Management, 94, 918926.

Pons M.N., Alinsafi A., Khemis M., Lerclerc J.P., Yaocoubi A., Benhammou A. and Nejmeddine A. (2005), Electrocoagulation of reactive textile dyes and textile wastewaters, Chemical Engineering and Processing, 44, 461-470.

Sari Erkan H., Yazici Güvenç S., Varank G. and Engin G. (2018), The investigation of chemical coagulation and electrocoagulation processes for tannery wastewater treatment using response surface methodology, Desalination and Water Treatment, 113, 57-73.

Sundrarajan M., Vishnu G. and Joseph K. (2007), Ozonation of light-shaded exhausted reactive dye bath for reuse, Dyes and Pigments, 75, 273-278.

Ulucan K. and Kurt U. (2015), Comparative study of electrochemical wastewater treatment processes for bilge water as oily wastewater: a kinetic approach, Journal of Electroanalytical Chemistry, 747, 104-111.

Ulucan-Altuntas K. and İlhan F. (2018), Enhancing biodegradability of the textile wastewater by ozonation process: optimization with response surface methodology, Ozone-Science \& Engineering, 6, 465-472. 